\title{
Stereoselective synthesis of the C79-C97 fragment of symbiodinolide
}

\author{
Hiroyoshi Takamura*1, Takayuki Fujiwara ${ }^{1}$, Isao Kadota*1 \\ and Daisuke Uemura ${ }^{2}$
}

Open Access

\author{
Letter \\ Address: \\ ${ }^{1}$ Department of Chemistry, Graduate School of Natural Science and \\ Technology, Okayama University, 3-1-1 Tsushimanaka, Kita-ku, \\ Okayama 700-8530, Japan and 2Department of Chemistry, Faculty of \\ Science, Kanagawa University, 2946 Tsuchiya, Hiratsuka 259-1293, \\ Japan \\ Email: \\ Hiroyoshi Takamura* - takamura@cc.okayama-u.ac.jp; Isao Kadota* - \\ kadota-i@cc.okayama-u.ac.jp \\ ${ }^{*}$ Corresponding author \\ Keywords: \\ Julia-Kocienski olefination; polyol marine natural product; Sharpless \\ asymmetric dihydroxylation; spiroacetalization; symbiodinolide
}

Beilstein J. Org. Chem. 2013, 9, 1931-1935.

doi:10.3762/bjoc. 9.228

Received: 18 July 2013

Accepted: 03 September 2013

Published: 25 September 2013

This article is part of the Thematic Series "Natural products in synthesis and biosynthesis".

Guest Editor: J. S. Dickschat

(C) 2013 Takamura et al; licensee Beilstein-Institut.

License and terms: see end of document.

\section{Abstract}

Symbiodinolide is a polyol marine natural product with a molecular weight of 2860 . Herein, a streamlined synthesis of the C79-C97 fragment of symbiodinolide is described. In the synthetic route, a spiroacetalization, a Julia-Kocienski olefination, and a Sharpless asymmetric dihydroxylation were utilized as the key transformations.

\section{Findings}

A 62-membered polyol marine natural product, symbiodinolide (1, Figure 1), was isolated from the $80 \%$ aqueous ethanol extract of the cultured symbiotic dinoflagellate Symbiodinium sp. in 2007 [1]. Symbiodinolide shows voltage-dependent $\mathrm{N}$-type $\mathrm{Ca}^{2+}$ channel-opening activity at $7 \mathrm{nmol} / \mathrm{L}$ and COX-1 inhibitory effect at $2 \mu \mathrm{mol} / \mathrm{L}$ (65\% inhibition). Furthermore, 1 ruptures the tissue surface of the acoel flatworm Amphiscolops sp. at $2.5 \mu \mathrm{mol} / \mathrm{L}$. The entire planar structure of 1 was established by the detailed 2D NMR spectroscopic analysis. However, the complete stereostructural determination of $\mathbf{1}$ with its 61 chirality centres and a molar mass of 2860 has been an unsolved issue. Therefore, in order to complete the configurational elucidation of $\mathbf{1}$, we are now investigating its chemical degradation [1-3] and chemical synthesis of the fragments [4-11].

Previously, we reported the stereoselective synthesis of the spiroacetal C79-C96 fragment [4], which is summarized in Scheme 1. Triflate 2 was reacted with the lithium acetylide prepared from alkyne 3 to give the desired coupling product 4 . The TBDPS ether $\mathbf{4}$ was transformed to TIPS ether $\mathbf{5}$ because of the lability of the TBDPS protecting group under the following Birch conditions. The alkyne 5 was subjected to the Birch reduction to afford the trans-alkene $\mathbf{6}$, wherein the benzyl 


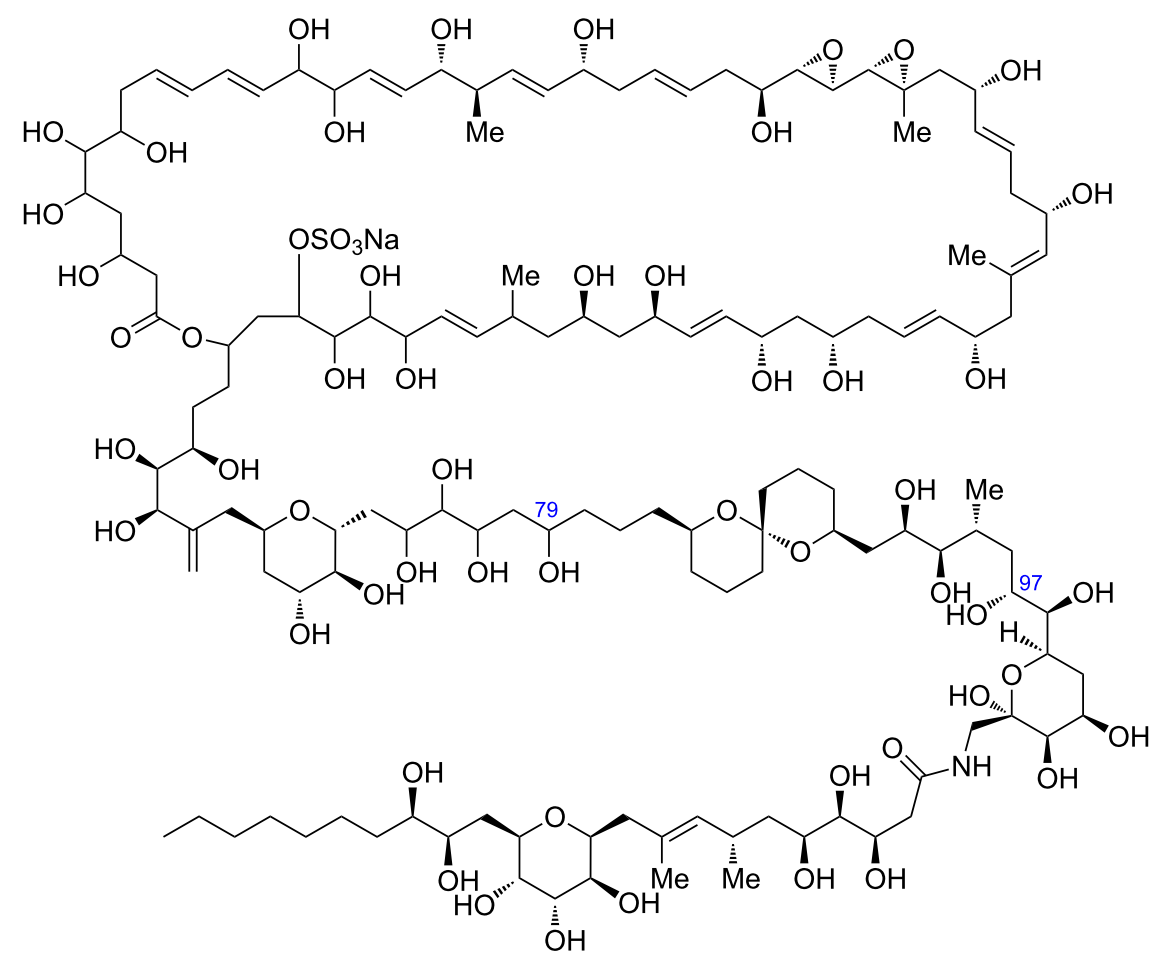

Figure 1: Structure of symbiodinolide (1).

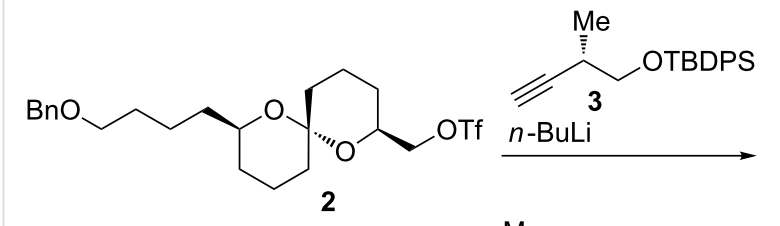

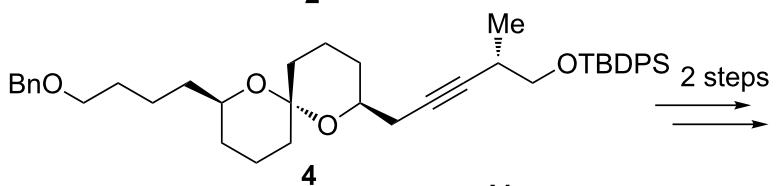<smiles>CC(C#CCC1CCC[C@]2(CCC(CCCCOc3ccccc3)O[C@@H]2C)O1)C[OH+][SbH2]</smiles><smiles>CCCS[OH+]CC(C)C=CCC1CCCC2(CCCC(CCCCO)O2)O1</smiles>

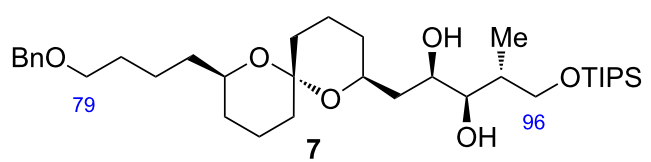

8 steps from the coupling

Scheme 1: Our previous synthesis of the C79-C96 fragment 7. moiety was deprotected. The alkene $\mathbf{6}$ was derivatized to the spiroacetal C79-C96 fragment 7 in four steps including the benzyl protection and Sharpless asymmetric dihydroxylation (AD). Although the desired spiroacetal fragment 7 was synthesized stereoselectively, the transformation starting with the coupling between $\mathbf{2}$ and $\mathbf{3}$ to the final product $\mathbf{7}$ needed eight steps. Therefore, we decided to examine the more efficient synthesis of the spiroacetal fragment. Herein, we report the improved synthesis of the spiroacetal fragment by utilizing Julia-Kocienski olefination as the coupling reaction.

The new retrosynthetic analysis of the C79-C97 fragment 8 is described in Scheme 2. We envisaged that the diol 8 could be synthesized by the Julia-Kocienski olefination [12-14] between aldehyde 9 and 1-phenyl-1H-tetrazol-5-yl (PT)-sulfone 10 and subsequent Sharpless AD [15], wherein the target molecule 8 could be prepared in two steps from the coupling. The carbon framework of 9 could be constructed through the stereoselective spiroacetalization of dihydroxyketone $\mathbf{1 1}$.

First, we commenced the stereocontrolled synthesis of aldehyde 20 (Scheme 3). Treatment of epoxide 13, which was prepared from L-aspartic acid (12) by the known procedure [8], with 3-butenylmagnesium bromide/CuI [16] provided the corresponding secondary alcohol. Protection of the alcohol with 


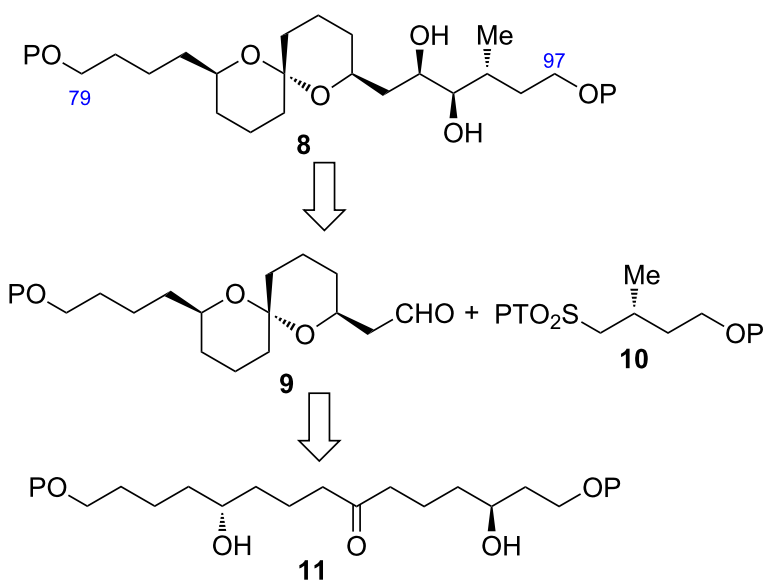

Scheme 2: Retrosynthetic analysis of the C79-C97 fragment 8.

TBSCl afforded TBS ether 14 in 91\% yield in two steps. Alkene $\mathbf{1 4}$ was reacted with $m$-CPBA to produce epoxide $\mathbf{1 5}$ as a $1: 1$ diastereomeric mixture. Epoxide 15 was coupled with alkyne 16 [4] in the presence of $n$-BuLi/BF $3 \cdot \mathrm{OEt}_{2}$ [17] to give the desired product $\mathbf{1 7}$ in $92 \%$ yield from $\mathbf{1 5}$. Hydrogenation of the alkyne moiety of $\mathbf{1 7}$ followed by TPAP oxidation [18] yielded ketone 18. Removal of the three TBS protecting groups and subsequent stereoselective spiroacetalization were performed in onepot with $\mathrm{CSA}$ in $\mathrm{MeOH}$ to provide spiroacetal 19 as a single stereoisomer [19,20]. The stereochemistry of 19 was elucidated by the observed NOE correlations between H-83 and H-91 as indicated by an arrow. The plausible rationale for the stereoselective formation of $\mathbf{1 9}$ is the thermodynamic stability due to the double anomeric effect. Oxidation of the alcohol 19 with $\mathrm{SO}_{3} \cdot \mathrm{pyr} / \mathrm{Et}_{3} \mathrm{~N} / \mathrm{DMSO}[21]$ afforded aldehyde $\mathbf{2 0}$.

Next, we carried out the synthesis of PT-sulfones $\mathbf{2 3}$ and $\mathbf{2 4}$ which were the coupling partners of the aldehyde $\mathbf{2 0}$ (Scheme 4). The synthesis started from commercially available methyl (S)-3-hydroxy-2-methylpropanoate (21), which was converted to alcohol 22 by the known method [22]. Alcohol 22 was treated with 1 -phenyl- $1 H$-tetrazole-5-thiol/DEAD/PPh 3 to furnish the corresponding PT-sulfide, which was oxidized with

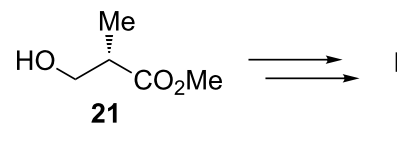<smiles></smiles>

1) 1 -phenyl- $1 H$-tetrazole-5-thiol $\mathrm{DEAD}, \mathrm{PPh}_{3}, \mathrm{THF}, 0^{\circ} \mathrm{C}$

2) $\mathrm{H}_{2} \mathrm{O}_{2},\left(\mathrm{NH}_{4}\right)_{6} \mathrm{Mo}_{7} \mathrm{O}_{24} \cdot 4 \mathrm{H}_{2} \mathrm{O}$

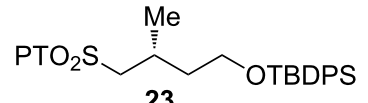
$\mathrm{EtOH}, 0$ to $40{ }^{\circ} \mathrm{C}$

$69 \%$ (2 steps)

1) $\mathrm{CSA}, \mathrm{MeOH}, 40^{\circ} \mathrm{C}$

2) TBSCl, imidazole, $\mathrm{CH}_{2} \mathrm{Cl}_{2}$, rt<smiles>[Z10]C(C)CCO[SbH2]</smiles>
$92 \%$ (2 steps)

Scheme 4: Synthesis of PT-sulfones 23 and 24.
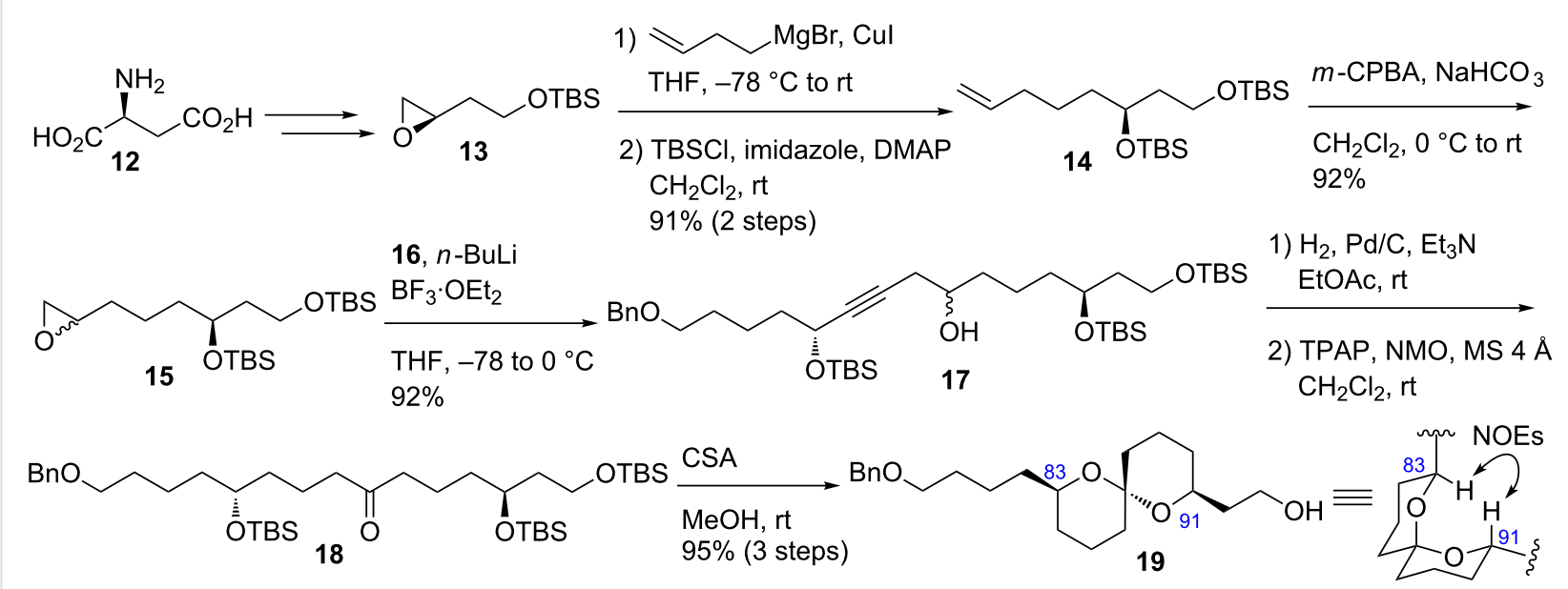

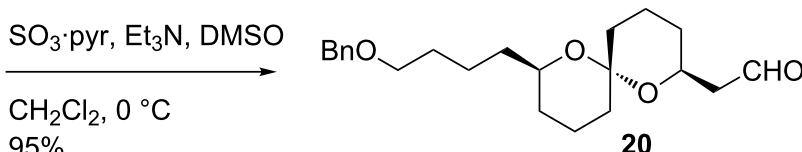<smiles>C#C[C@H]([Se-])CCCCOc1ccccc1</smiles> 
$\mathrm{H}_{2} \mathrm{O}_{2} / \mathrm{Mo}$ (VI) [23] to yield PT-sulfone 23. The TBDPS protecting group of $\mathbf{2 3}$ was transformed to the TBS group in two steps to provide PT-sulfone 24 .

With the coupling precursors aldehyde $\mathbf{2 0}$ and PT-sulfones $\mathbf{2 3}$ and $\mathbf{2 4}$ in hand, we next examined the Julia-Kocienski olefination [12-14] of these compounds (Table 1). Deprotonation of the PT-sulfone $\mathbf{2 3}$ with KHMDS, followed by addition of the aldehyde 20, gave rise to the desired coupling product $(E)-\mathbf{2 5}$ along with $(Z)-\mathbf{2 5}$ in 27\% combined yield at a 3.5:1 diastereomeric ratio (Table 1, entry 1). When NaHMDS was used as the base, the chemical yield was improved to $77 \%$, however, the $E / Z$ ratio was decreased to $1.3: 1$ (Table 1 , entry 2 ). When LDA was used as the base, the chemical yield and diastereomeric ratio were increased to $98 \%$ and 2.6:1, respectively (Table 1 , entry 3). Reaction of PT-sulfone $\mathbf{2 4}$ using LDA gave the coupling products $(E)$ - and $(Z)-26$ in $86 \%$ yield, wherein the diastereomeric ratio was increased to 5.0:1 (Table 1, entry 4). The configurations of the coupling products were elucidated by their coupling constants between H-93 and H-94 (15.3 Hz in $(E)-25$ and $(E)-26,10.7 \mathrm{~Hz}$ in (Z)-25 and (Z)-26). Finally, the desired alkene $(E)-\mathbf{2 6}$ was subjected to the Sharpless AD [15] with AD-mix- $\beta$ to furnish the C79-C97 fragment 27 in $72 \%$ yield as a single diastereomer (Scheme 5). The configuration of the resulting two vicinal hydroxy groups at C93 and C94 of 27 were unambiguously confirmed by the modified Mosher method, respectively (see Supporting Information File 1).

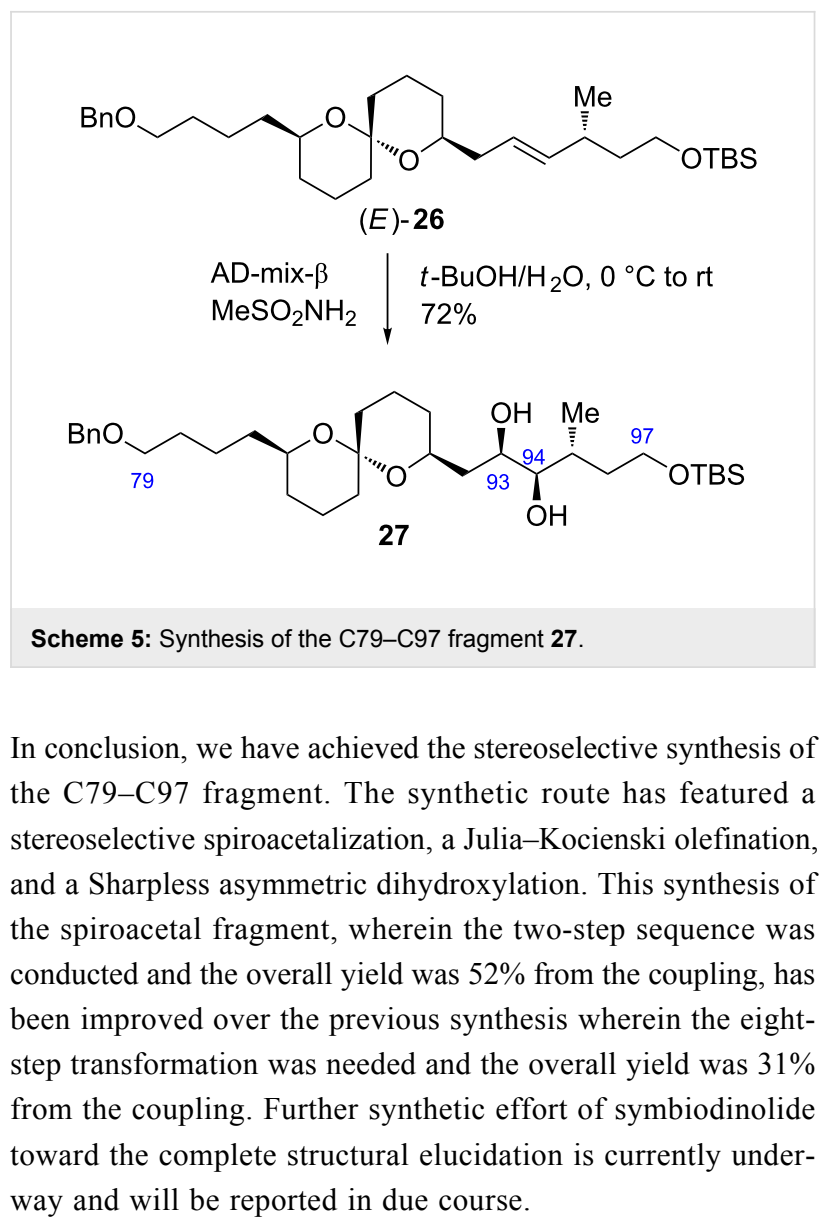

Table 1: Julia-Kocienski olefination between aldehyde $\mathbf{2 0}$ and PT-sulfones $\mathbf{2 3}$ and $\mathbf{2 4 .}$<smiles>O=CCC1CCC[C@]2(CCC[C@@H](CCCCOCc3ccccc3)O2)O1</smiles>

20

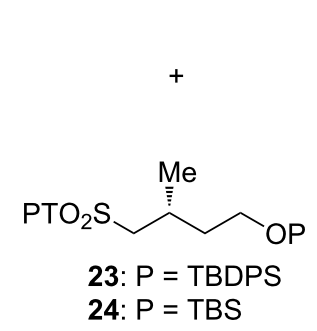<smiles>CC(C=CCC1CCC[C@@]2(CCC[C@@H](CCCCOCc3ccccc3)O2)O1)CCOCc1ccccc1</smiles>

(E)-25: $\mathrm{P}=$ TBDPS

(E)-26: $\mathrm{P}=\mathrm{TBS}$

${ }^{3} J_{\mathrm{H} 93, \mathrm{H} 94}=15.3 \mathrm{~Hz}$<smiles>CC(/C=C\CC1CCC[C@]2(CCC[C@H](CCCCOCc3ccccc3)O2)O1)CCOP</smiles>

(Z)-26: $P=$ TBS

${ }^{3} J_{\mathrm{H} 93, \mathrm{H} 94}=10.7 \mathrm{~Hz}$

\begin{tabular}{lllll}
\hline Entry & PT-Sulfone & Base & ${\text { Yield }(\%)^{\mathrm{a}}}$ & ${\text { Ratio }(E: Z)^{\mathrm{b}}}^{\mathrm{b}}$ \\
\hline 1 & $\mathbf{2 3}$ & KHMDS & 27 & $3.5: 1$ \\
2 & $\mathbf{2 3}$ & NaHMDS & 77 & $1.3: 1$ \\
3 & $\mathbf{2 3}$ & LDA & 98 & $2.6: 1$ \\
4 & $\mathbf{2 4}$ & LDA & 86 & $5.0: 1$ \\
\hline
\end{tabular}

alsolated yield from 20. ${ }^{b}$ Determined by ${ }^{1} \mathrm{H}$ NMR spectroscopy. 


\section{Supporting Information}

\section{Supporting Information File 1}

Experimental procedures, spectroscopic data, and NMR spectra of all new compounds.

[http://www.beilstein-journals.org/bjoc/content/ supplementary/1860-5397-9-228-S1.pdf]

\section{Acknowledgements}

We are grateful to Mr. Yohei Kawakubo (Okayama University) for valuable discussions. We acknowledge The Kurata Memorial Hitachi Science and Technology Foundation, The Research Foundation for Pharmaceutical Sciences, and The Society of Synthetic Organic Chemistry, Japan (Shionogi Award in Synthetic Organic Chemistry, Japan) for financial supports. This research was supported by a Grant-in-Aid for Scientific Research (No. 24710250) from the Japan Society for the Promotion of Science (JSPS).

\section{References}

1. Kita, M.; Ohishi, N.; Konishi, K.; Kondo, M.; Koyama, T.; Kitamura, M.; Yamada, K.; Uemura, D. Tetrahedron 2007, 63, 6241-6251. doi:10.1016/j.tet.2007.02.093

2. Han, C.; Uemura, D. Tetrahedron Lett. 2008, 49, 6988-6990. doi:10.1016/j.tetlet.2008.09.118

3. Han, C.; Yamano, Y.; Kita, M.; Takamura, H.; Uemura, D. Tetrahedron Lett. 2009, 50, 5280-5282. doi:10.1016/j.tetlet.2009.07.014

4. Takamura, H.; Ando, J.; Abe, T.; Murata, T.; Kadota, I.; Uemura, D. Tetrahedron Lett. 2008, 49, 4626-4629. doi:10.1016/j.tetlet.2008.05.078

5. Murata, T.; Sano, M.; Takamura, H.; Kadota, I.; Uemura, D. J. Org. Chem. 2009, 74, 4797-4803. doi:10.1021/jo900546k

6. Takamura, H.; Murata, T.; Asai, T.; Kadota, I.; Uemura, D. J. Org. Chem. 2009, 74, 6658-6666. doi:10.1021/jo901162v

7. Takamura, H.; Kadonaga, Y.; Yamano, Y.; Han, C.; Aoyama, Y.; Kadota, I.; Uemura, D. Tetrahedron Lett. 2009, 50, 863-866. doi:10.1016/j.tetlet.2008.11.056

8. Takamura, H.; Kadonaga, Y.; Yamano, Y.; Han, C.; Kadota, I.; Uemura, D. Tetrahedron 2009, 65, 7449-7456. doi:10.1016/j.tet.2009.07.019

9. Takamura, H.; Kadonaga, Y.; Kadota, I.; Uemura, D. Tetrahedron Lett. 2010, 51, 2603-2605. doi:10.1016/j.tetlet.2010.03.014

10. Takamura, H.; Kadonaga, Y.; Kadota, I.; Uemura, D. Tetrahedron 2010, 66, 7569-7576. doi:10.1016/j.tet.2010.07.045

11. Takamura, H.; Tsuda, K.; Kawakubo, Y.; Kadota, I.; Uemura, D. Tetrahedron Lett. 2012, 53, 4317-4319. doi:10.1016/j.tetlet.2012.06.005

12. Blakemore, P. R.; Cole, W. J.; Kocieński, P. J.; Morley, A. Synlett 1998, 26-28. doi:10.1055/s-1998-1570

13. Aïssa, C. Eur. J. Org. Chem. 2009, 1831-1844. doi:10.1002/ejoc.200801117

14. Blakemore, P. R. J. Chem. Soc., Perkin Trans. 1 2002, 2563-2585. doi:10.1039/B208078H
15. Kolb, H. C.; VanNieuwenhze, M. S.; Sharpless, K. B. Chem. Rev. 1994, 94, 2483-2547. doi:10.1021/cr00032a009

16. Paterson, I.; Anderson, E. A.; Dalby, S. M.; Lim, J. H.; Maltas, P.; Loiseleur, O.; Genovino, J.; Moessner, C. Org. Biomol. Chem. 2012, 10, 5861-5872. doi:10.1039/c2ob25100k

17. Yamaguchi, M.; Hirao, I. Tetrahedron Lett. 1983, 24, 391-394. doi:10.1016/S0040-4039(00)81416-1

18. Ley, S. V.; Norman, J.; Griffith, W. P.; Marsden, S. P. Synthesis 1994, 639-666. doi:10.1055/s-1994-25538

19. Perron, F.; Albizati, K. F. Chem. Rev. 1989, 89, 1617-1661. doi:10.1021/cr00097a015

20. Aho, J. E.; Pihko, P. M.; Rissa, T. K. Chem. Rev. 2005, 105, 4406-4440. doi:10.1021/cr050559n

21. Parikh, J. R.; Doering, W. v. E. J. Am. Chem. Soc. 1967, 89, 5505-5507. doi:10.1021/ja00997a067

22. Kurosawa, S.; Mori, K. Eur. J. Org. Chem. 2000, 955-962. doi:10.1002/(SICI)1099-0690(200003)2000:6<955::AID-EJOC955>3.0. $\mathrm{CO} ; 2-\mathrm{Y}$

23. Schultz, H. S.; Freyermuth, H. B.; Buc, S. R. J. Org. Chem. 1963, 28, 1140-1142. doi:10.1021/jo01039a512

\section{License and Terms}

This is an Open Access article under the terms of the Creative Commons Attribution License (http://creativecommons.org/licenses/by/2.0), which permits unrestricted use, distribution, and reproduction in any medium, provided the original work is properly cited.

The license is subject to the Beilstein Journal of Organic Chemistry terms and conditions:

(http://www.beilstein-journals.org/bjoc)

The definitive version of this article is the electronic one which can be found at: doi:10.3762/bjoc. 9.228 